\title{
Geochemical Assessments and Potential Energy Sources Evaluations Based on Oil Shale and Geothermal Resource in Wadi Al-Shallala-North Jordan
}

\author{
Haneen Al Dhoun, Sana'a Al-Zyoud* \\ Department of Applied Earth and Environmental Sciences, Institute of Earth and Environmental Sciences, Al al-Bayt University, \\ Al Mafraq, Jordan \\ Email: *alzyoud@aabu.edu.jo
}

How to cite this paper: Al Dhoun, H. and Al-Zyoud, S. (2019) Geochemical Assessments and Potential Energy Sources Evaluations Based on Oil Shale and Geothermal Resource in Wadi Al-Shallala-North Jordan. International Journal of Geosciences, 10, 351-365.

https://doi.org/10.4236/ijg.2019.103020

Received: February 10, 2019

Accepted: March 26, 2019

Published: March 29, 2019

Copyright $\odot 2019$ by author(s) and Scientific Research Publishing Inc. This work is licensed under the Creative Commons Attribution International License (CC BY 4.0).

http://creativecommons.org/licenses/by/4.0/

\begin{abstract}
Oil shale deposit is considered as one of the fossil fuel sources in Jordan. Despite that, the needs of renewable energy resources become a must in Jordan. Wadi Al-Shallala oil shale is investigated in this work for geochemical, petrographic features and hydrocarbon potential as a conventional energy resource. Various petrographic and geochemical techniques were applied. Oil shale resource potential is evaluated for cooling and heating Sal village houses. Geothermal heat pumps, as renewable energy resource in the study area, were simulated for comparison purposes. Results show that Calcite is the main mineral component of oil shale. Magnesite, Ferrisilicate and Zaherite are exhibited in the studied samples. Other trace elements of Zinc, Cobalt and Molybdenum were presented, too. Calcium oxide of $41.01 \%$ and Silicon oxide of $12.4 \%$ are the main oxides reflected in this oil shale. Petrographic features of the analyzed oil shale found that the primary mineral constituent is micritic calcite, while the secondary minerals include carbonate mud and opaque minerals. Furthermore, it's found that total organic carbon averages 3.33\% while the total carbon content averages $20.6 \%$. Moderate TOC values suggest that Wadi Al-Shallala oil shale has a good source rock potential. Even though nitrogen and sulfur are of low contents in Wadi Al-Shallala oil shale, direct combustion of the reserve for electricity generating will increase $\mathrm{CO}_{2}$ emissions by 2.71 Million $\mathrm{m}^{3}$. Two systems were simulated to cover Sal village cooling and heating demands. The conventional system is compared with geothermal heat pumps. Geothermal heat pumps are found to save $60 \%$ of electricity consumption in heating and $50 \%$ in cooling systems. The environmental benefits for geothermal system implementation will be a reduction
\end{abstract}


in energy consumption as electricity. The savings in fuel oil will be about 9.35 Million barrels. While the reduction of $\mathrm{CO}_{2}$ emissions will drop to 1.5 Million

$\mathrm{m}^{3}$. Results suggest that geothermal heat pumps are the best for satisfying cooling and heating needs in Sal village near Wadi Al-Shallala.

\section{Keywords}

Oil Shale Geochemistry and Hydrocarbon Potential, Geothermal Heat

Pumps, Cooling and Heating Systems, Wadi Al-Shallala, Jordan

\section{Introduction}

Conventional energy used in Jordan is the major supply source; it satisfies more than $90 \%$ of energy demand in Jordan. One of the most important energy resources in Jordan is oil shale [1]. Oil shale reserves in Jordan were evaluated recently by [2] and [3]. They stated that surface and subsurface oil shale rocks in Jordan have a considerable economic potential for Jordan. Their work focuses on central and southern oil shale deposits in Jordan. They presented a brief characterization of four oil shale deposits. Size distribution test and elemental analysis were performed. Hydrocarbon potential evaluations of oil shale are considered as an indicator for this source potential [1]. Furthermore, oil shale evaluations are of utmost importance for future utilization in Jordan. [4] suggested several utilization methods of oil shale in Jordan and worldwide. Most of previous work evaluated Jordanian oil shale in middle and south Jordan ([1]; [2]; [3]; [4]; [5]). It has been found that oil shale is the most abundant fossil energy resource discovered in Jordan, ranking third after the USA and Brazil in terms of oil shale reserves [5]. In addition, it was concluded that Jordanian oil shale is generally of a good quality, with relatively low ash and moisture contents, a gross calorific value of $7.5 \mathrm{MJ} / \mathrm{kg}$, and a wide range of oil yield of $3 \%$ to $12 \%$ [5]. Oil shale in north Jordan has very limited evaluation studies. Therefore, this work will evaluate heat potential of oil shale in Wadi Al-Shallala in north Jordan.

On the other hand, the increasing demands of environmentally friendly energy resources convert the attention to other renewable resources. One of the newest renewable energies in Jordan is geothermal energy ([6]; [7]; [8]). Shallow geothermal energy resources are rather used in Jordan [7]. It can utilize the subsurface temperature as it differs from air temperature. Thus, it would be an environmental and sustain heat exchanger. The ground can be utilized as heat source in winter and cool source in summer. Thus, unlike other energy resources that require advanced technical setups, geothermal energy exploits the natural heat (and cool) from the earth. In order to extract this energy a closed loop of horizontal installed pipes, which filled with heat carrier fluid inside, is circulating in subsurface. This circulation is responsible for heat transfer from/to the subsurface to/from buildings systems, where a heat pump is often applied [9]. Closed loop geothermal system for nearby village of Wadi Al Shallala is 
modeled. Sal is located to the east of Irbid city. Its area is about 9 square kilometers with a population of about 12,000 per capita. 2270 houses were considered for their cooling and heating demands in this study. Consequently, this work aims at highlighting the possible energy sources in Wadi Al-Shallala. In parallel with the oil shale, geothermal resource is evaluated for prospective energy production. The possibility of supplying buildings with heat and cool is evaluated. Oil shale is suggested as the first energy supplier, electricity form. Shallow geothermal heat pumps with closed loop are simulated as the second energy supplier. Thus, potential evaluations were calculated for both resources in Wadi Al-Shallala and Sal village.

There is a need and an opportunity for targeted potential energy utilization that support research which connects energy resources development and the available infrastructure. On the other hand, an increased necessity for supporting work that focuses specifically on addressing important gaps in understanding the social, economic and environmental implications of expanding alternative energy systems. The literature was reviewed to identify potential knowledge gaps. This will suggest an immediate path forward: the interpretation of the national literature for the Jordanian energy context. In addition, a key challenge for policy makers and researchers is to understand and acknowledge what we know about the impacts of alternative energy systems and which of those gaps require attention. This will lead to looking for immediate research opportunities: the interpretation of the national literature for the energy context to best identify knowledge, and relevant experiences and cases. Therefore, the present work addressing to fill potential knowledge gaps in energy utilization in Jordan.

\section{Geologic Settings}

Wadi Al Shallala is located in north Jordan about 12 kilometers northeast of Irbid City and 5 kilometers northwest of A-Ramtha City. It has $19 \mathrm{~km}$ long extension in SE-NW direction (Figure 1). Wadi Al Shallala covers an area of around $500 \mathrm{~km}^{2}$ as a part of Yarmouk River Basin [10]. The upper $10 \mathrm{~m}$ thickness, from around 40 $\mathrm{m}$ total thickness in the valley, is investigated in this work. The coordinates of the outcrop are $\left(32^{\circ} 35^{\prime} 28^{\prime \prime} \mathrm{N}\right)\left(35^{\circ} 57^{\prime} 46^{\prime \prime} \mathrm{E}\right)$. Most of the oil shale is overburden under and intercalated chert, limestone and chalk. Oil shale in Wadi Al-Shallala located at the upper one third part of Muwaqqar Chalk Marl formation.

Wadi Al-Shallala Oil Shale is of Late Cretaceous (Maastrichtion) to early Tertiary age. It was deposited in an open, normal marine environment [11]. The study area is covered by Balqa Group including the following formations (Figure 1): Muwaqqar Chalk Marl (MCM), Umm Rijam Chert Limestone (URC) and Wadi Al-Shallala Chalk Formation (WSC). MCM is soft, thick-bedded chalky-marl with chalky limestone of 120 to $320 \mathrm{~m}$ thickness. Nodules of microcrystalline limestone and chert, planktonic and benthic foraminifera are common. MCM is of Maastrichtian to Paleocene age [11]. URC of $220 \mathrm{~m}$ thick consists of marly chalk, white limestone with bituminous limestone and 


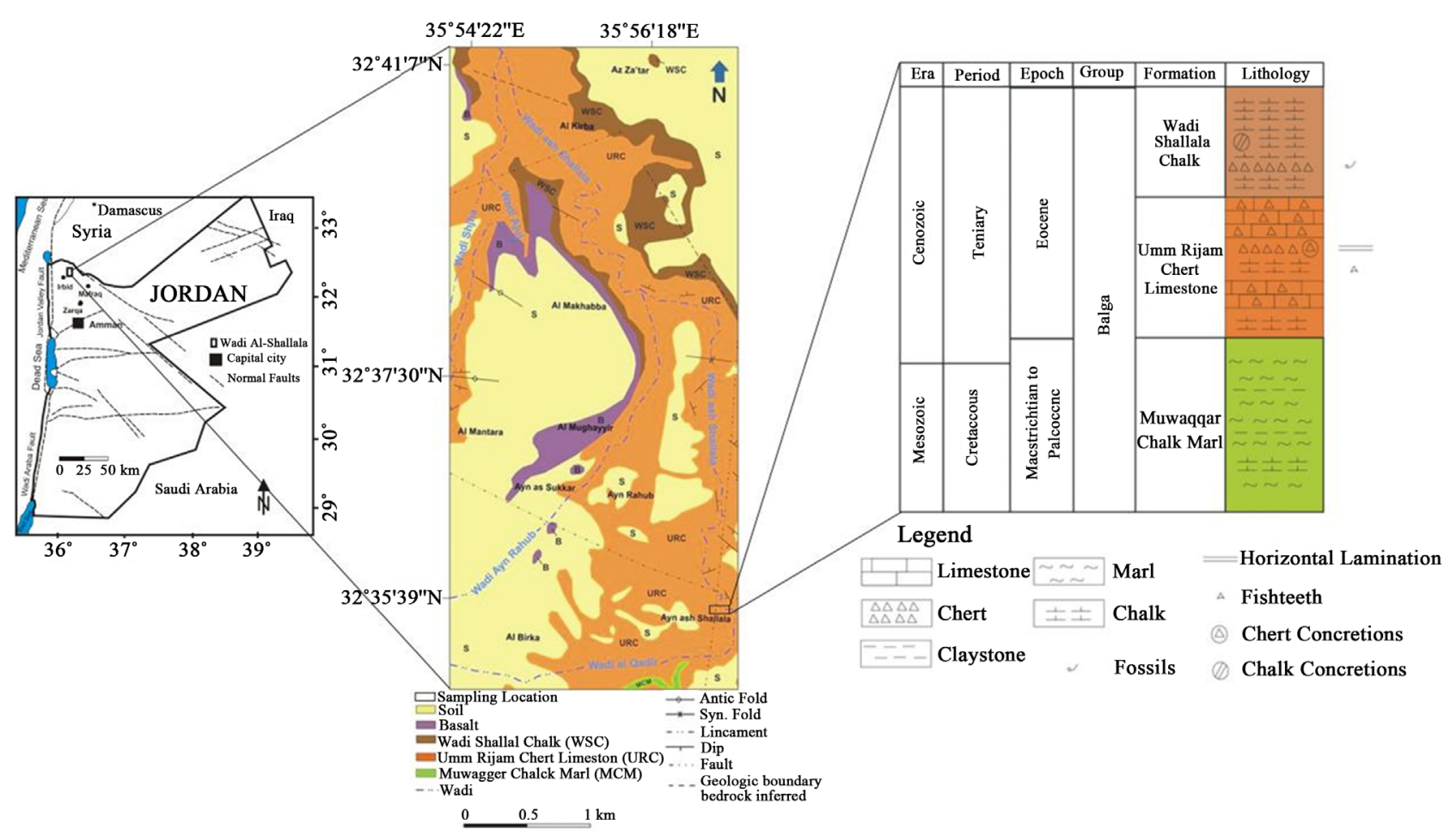

Figure 1. Geologic map and geologic cross section of the study area (after [11] \& [12]).

chert. It's of Lower-Middle Eocene age [12]. WSC Formation is $100 \mathrm{~m}$ thick of Middle to Upper Eocene age. It consists mainly of chalk, marl and micritic limestone [13].

\section{Methodology}

\subsection{Oil Shale Characterization}

Thirty oil shale samples had been collected vertically along the outcrop. The samples, for technical circumstances, were collected at $20-50 \mathrm{~cm}$ in depth, as fresh as possible. The lower sample was at an elevation of $429 \mathrm{~m}$ (above sea level). The samples were collected apart $25 \mathrm{~cm}$ from each other. Each sample was approximately $500 \mathrm{gm}$. The sampling was in summer, at June, thus the samples had a little amount of humidity. The samples were air dried and packed in plastic bags in the field. The sample then had been prepared in the lab for each test independently. Investigated oil shale samples were prepared in the lab to be examined for its chemical composition, mineral constituents and carbon potential. The following analyses were performed; 1) Elemental Analysis (EA), 2) X-Ray Diffraction (XRD), 3) X-Ray Fluorescence (XRF), 4) Scanning Electron Microscope (SEM) and 5) Polarized Light Microscopy Analysis of Thin Section.

The analyses were carried out as follows:

1) Elemental Analyzer is used to measure carbon content of the studied samples. The sample is pulverized and chemically treated with hot diluted $20 \% \mathrm{HCL}$ to remove its inorganic carbon in the form of carbon dioxides $\mathrm{CO}_{2}$. After that, the sample is washed free of HCL solution, filtered and collected in a specified 
bag then sent to Elemental Analyzer. Organic carbon combustion products of the sample are catalytically converted to $\mathrm{CO}_{2}$ and measured by Elemental Analyzer [14]. In addition to the organic carbon content, nitrogen, hydrogen and sulfur constituents for organic compounds were measured, too. Total carbon content (TCC) was measured for the examined samples, on $63 \mu \mathrm{m}$ grained size, using the calcimetry method [15]. Total organic carbon (TOC \%) was calculated as illustrated in Equation (1) below;

$$
\mathrm{TOC} \%=\left[\frac{\mathrm{OC}}{\mathrm{W}}\right] \times 100 \%
$$

where:

$$
\begin{aligned}
& \text { OC = Organic Carbon }(\mathrm{g}) \\
& \mathrm{W}=\text { Dry sample analysis }(\mathrm{g})
\end{aligned}
$$

Improving the sensitivity of analysis method with using a wide range of reference standard for calibration curve determination has been developed [16].

2) X-Ray Diffraction is an atomic plane used for phase identification of crystalline material in order to obtain detailed information about their structure samples. Each sample has been grinded to $(75 \mu \mathrm{m})$ size. The powdered samples were packed into a cavity at a flat surface on the backside of the XRD sample holder.XRD measurements were performed in a Shimadzu Lab X, XRD-6000 $\mathrm{X}$-ray diffractometer using $\mathrm{Cu} \mathrm{KL2}, 3(\alpha 1,2)$ radiation $(\lambda=1.5418 \AA, 40 \mathrm{kV})$ and it ranges from $\left(2^{\circ}\right.$ to $\left.80^{\circ}\right) 2 \theta$ with a step size of $0.05^{\circ} 2 \theta$. The assignment of the minerals was based on the database of the Joint Committee Powder Diffraction Standards-International Centre for Diffraction Data (JCPDS-ICDD) [17].

3) $\mathrm{X}$-Ray fluorescence is applied to determine the major oxides $\left(\mathrm{SiO}_{2}, \mathrm{Al}_{2} \mathrm{O}_{3}\right.$, $\mathrm{Fe}_{2} \mathrm{O}_{3}, \mathrm{MgO}, \mathrm{CaO}, \mathrm{Na}_{2} \mathrm{O}, \mathrm{K}_{2} \mathrm{O}, \mathrm{TiO}_{2}, \mathrm{P}_{2} \mathrm{O}_{5}, \mathrm{SO}_{3}$ and $\mathrm{MnO}$ ) in the studies oil shale samples. This method provides a comparable accuracy for analysis of oil shale. Inter element and matrix effects are treated by different methods; matrix matching of samples and standards (dilution by lithium tetra borate $\mathrm{Li}_{2} \mathrm{~B}_{4} \mathrm{O}_{7}$ ) and mathematical corrections during data export have been implemented. $\mathrm{Au}$ tomatic fusion technique, for presenting the best homogeneity samples, has been applied. Thus, the examined samples were milled to give a flat surface. The powder reduces particle size effect. The samples then pressed into pellets for best handling fusion with a suitable flux of glass-like beads. This is the best practice for eliminating errors with materials which exhibit varying mineralogical composition [18].

4) Scanning Electron Microscope had scanned the oil shale samples with a focused beam of electrons. The Elemental composition of fine to microscopic particles or regions on a surface of samples are analyzed using an energy dispersive $\mathrm{x}$-ray spectrometer (EDS) attached to the SEM. Samples have to be prepared to withstand the vacuum conditions and high energy beam of electrons. The examined sample has to be of a specific size fits on the specimen stage. Samples should be mounted to a specimen holder or stub using a conductive adhesive [19]. 
5) Polarized Light Microscopy Analysis of Thin Sections was conducted under polarizing microscope. They had been investigated with two light positions; plane polarized light and crossed polar light with two polarizing filters at the right angle are installed. Thin section s are pre-prepared at $30 \mu \mathrm{m} \pm 5 \mu \mathrm{m}$ thin slice of shale slab, having at least one glass slide glued to one of its sides with epoxy.

\subsection{Hydrocarbon Potential of Oil Shale Comparing with Geothermal Potential in the Study Area}

On the other hand, a suggested geothermal heat pumps for cooling and heating houses in Sal village, the nearest urban area to Wadi Al-Shallala, were modeled. Information about the subsurface temperature distribution in the study area is very limited. One subsurface temperature survey was conducted in central Jordan (about $200 \mathrm{~km}$ south to the study area) by [20]. Thus, an initial surface temperature distribution was estimated at $20^{\circ} \mathrm{C}$. The basal heat flow rate is 95 $\mathrm{m} \cdot \mathrm{W} \cdot \mathrm{m}^{-2}$ according to global heat flow data base [21]. Thermal conductivity of the subsurface is given from previous work as $2.36 \pm 0.32 \mathrm{~W} \cdot \mathrm{m}^{-1} \cdot \mathrm{K}^{-1}$ [22]. Comparing with available modeled subsurface temperature eastern to the study area [7] and the geothermal gradient in the study area [23] a temperature of $22^{\circ}$ was assigned to subsurface in Wadi Al-Shallala. To bring this temperature distribution into reality, a comparison with the nearest wells subsurface temperature has been done. Available data was match with the modeled temperature [24]. Shallow geothermal closed loop heat pump system was simulated for its cooling and heating potential. Different scenarios were applied dependent on the intake flow rate and system capacity for the suggested heat pumps.

For comparison purposes, oil shale reserve in the study area was estimated. Oil shale heat potential was calculated from oil shale reserve. The average organic matter content is then converted to energy (i.e.; electricity). This amount of energy was modeled for supplying houses with cooling and heating. The two energy types were compared in terms of their supply potential in the study area.

\section{Results and Discussion}

\subsection{Oil Shale Characterization}

\subsubsection{Elemental Analyzer (EA) Results}

Total Organic Carbon (TOC) is relatively low to moderate in the studied samples. It ranges between (1.297\% and $4.616 \%)$ with an average of $3.33 \%$, this is considered as a good hydrocarbon generating potential [25]. Total Carbon Content averages $20.6 \%$ and ranges between (10.95\% and $27.72 \%)$. Hydrocarbon potential could not be generated without originally enough organic matter content in the depositional environment. Therefore, the drop in TCC may be as a result of early organic matter loss at early stages of genesis. The planktonic/benthic ratio exhibits some fluctuations in the oil shale TOC probably as a consequence of relative sea-level changes. This method can be used as a quantitative method to calculate paleo depth based on a formula [26]. Low abundance 
of plankton in some samples can be associated with relative sea-level drop down. The decrease in abundance of planktonic foraminifera (52\% and $68 \%$ in samples 16 and 22, respectively) indicated the presence of shallower environments. Such environments provide more than $50 \%$ increase in oxygen. Consequently, this will lead to decline in organic matter accumulation due to aerobic biodegradation [27]. On the other hand, the samples revealed low quantities of sulfur and nitrogen as well. The average sulfur content in the examined samples is 3.5\% while the average nitrogen is $1.5 \%$.

\subsubsection{X-Ray Diffraction (XRD) Results}

XRD analysis of the oil shale indicates that the major mineral constituent is calcite. The maximum peak of calcite appears at the d-spacing $=3.02 \AA(2 \theta=$ 29.24). Trace constituents of Magnesite $\left(\mathrm{Mg}_{2}\left(\mathrm{CO}_{3}\right)_{2}\right)$, Ferrisilicite (FeSi) and $\mathrm{Za}$ herite $\mathrm{Al}_{12}\left(\mathrm{SO}_{4}\right)_{5}(\mathrm{OH})_{26}$ are presented, too. In addition, other rare elements are exhibited; Gupeiite $\left(\mathrm{Fe}_{3} \mathrm{Si}\right)$, Cobalt Oxide $(\mathrm{CoO})$, Magnesium Oxide $(\mathrm{MgO})$, Stillite ( $\mathrm{ZnSe})$, Cobalt Nitride $\left(\mathrm{Co}_{3} \mathrm{~N}_{2}\right)$ and Molybdenum disilicide $\left(\mathrm{MoSi}_{2}\right)$. XRD pattern for one sample is shown below at Figure 2.

Most of the indicated minerals have not been reported from this area so far. A comparison between other Jordanian oil shale [28] and Wadi Al-Shallala oil shale is performed in Table 1.

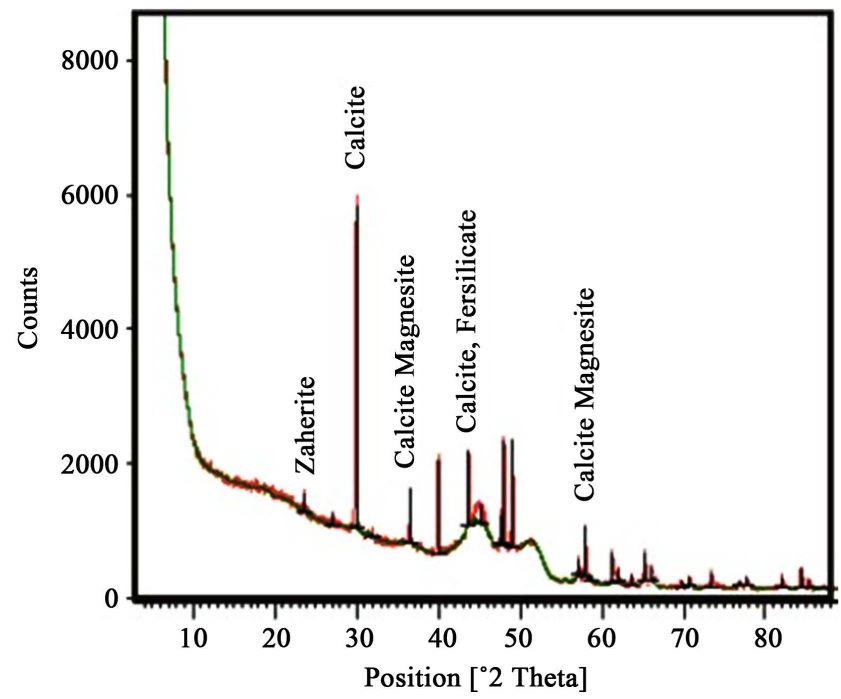

Figure 2. XRD results of the main mineral components of oil shale.

Table 1. Mineral components of the studied Oil shale compared with other oil shale in Jordan.

\begin{tabular}{ccccc}
\hline Wadi Al-Shallala & Sultani & El-Lajjun & Attarat Um Ghudran & Siwaqa \\
\hline Calcite & Quartz & Quartz & Calcite & Calcite \\
Magnesite & Clay & Kaolinite & Quartz & Quartz \\
Ferrsilicite & & Apatite & Apatite & Apatite \\
Zaherite & & & & Smectite \\
\hline
\end{tabular}




\subsubsection{X-Ray Fluorescence (XRF) Results}

The X-ray fluorescence (XRF) analyses show the presence of $41.01 \% \mathrm{CaO}$ and $12.4 \% \mathrm{SiO}_{2}$. In addition, high percentage of L.O.I with mean a value of $40.34 \%$ was obtained.

Loss on ignition in oil shale depends on the content of moisture organic matter, carbonate and volatile components mainly sulfur (although $\mathrm{SO}_{3}$ of the studied samples are higher than other Jordanian oil shale). Such lost occur after the samples exposure to a strong heating during the analysis.

According to [28] the percentage of $\mathrm{SiO}_{2}$ is low in Wadi Al-Shallala comparing to the high percentages in El-Lajjun and Attarat Um Ghudran. In contrast, $\mathrm{CaO} \%$ is of high percentage in Wadi Al-Shallala much more than in El-Lajjun and Attarat Um Ghudran. This is proven by XRD results were Calcite occupied the highest mineral component in the studied samples comparing with other Jordanian oil shale. The remaining oxides are within the average values of oil shale in Jordan (Table 2).

\subsubsection{Scanning Electron Microscope (SEM) Results}

SEM results of oil shale indicate that the highest element content is for Ca averages $31.68 \%$. The average oxygen content is $39.16 \%$ and average carbon is $22.77 \%$, indicate calcite mineral as the main component of this oil shale. In addition, $\mathrm{Si}$ averages $4.31 \%, \mathrm{~S}$ averages $1 \%, \mathrm{Al}$ averages 0.7 and $\mathrm{Mg}$ averages $0.4 \%$ in the studied samples. Figure 3 is SEM analysis results of one sample (No. 2) directed the mentioned elements above.

Table 2. Wadi Al-Shallala oil shale chemical composition compared with other oil shale in Jordan.

\begin{tabular}{cccc}
\hline Major oxides & Wadi Al-Shallala & Attarat Um Ghudran & El-Lajjun \\
\hline $\mathrm{SiO}_{2} \%$ & 12.4 & 23 & 16.13 \\
$\mathrm{TiO}_{2} \%$ & 0.0435 & 0.2 & 0.16 \\
$\mathrm{Al}_{2} \mathrm{O}_{3} \%$ & 1.92 & 2.7 & 3.77 \\
$\mathrm{Fe}_{2} \mathrm{O}_{3} \%$ & 0.835 & 0.9 & 1.55 \\
$\mathrm{MnO} \%$ & 0.006 & - & 0.01 \\
$\mathrm{MgO} \%$ & 0.81 & - & 0.65 \\
$\mathrm{CaO} \%$ & 41.01 & 25.6 & 30.43 \\
$\mathrm{Na}_{2} \mathrm{O} \%$ & - & 1.1 & 0.1 \\
$\mathrm{~K}_{2} \mathrm{O} \%$ & 0.305 & 0.3 & 0 \\
$\mathrm{P}_{2} \mathrm{O}_{5} \%$ & 1.265 & 2.4 & 3.3 \\
$\mathrm{SO}_{3} \%$ & 0.075 & 4 & 4.83 \\
$\mathrm{LOI}_{4}$ & 40.34 & - & 38.13 \\
\hline
\end{tabular}




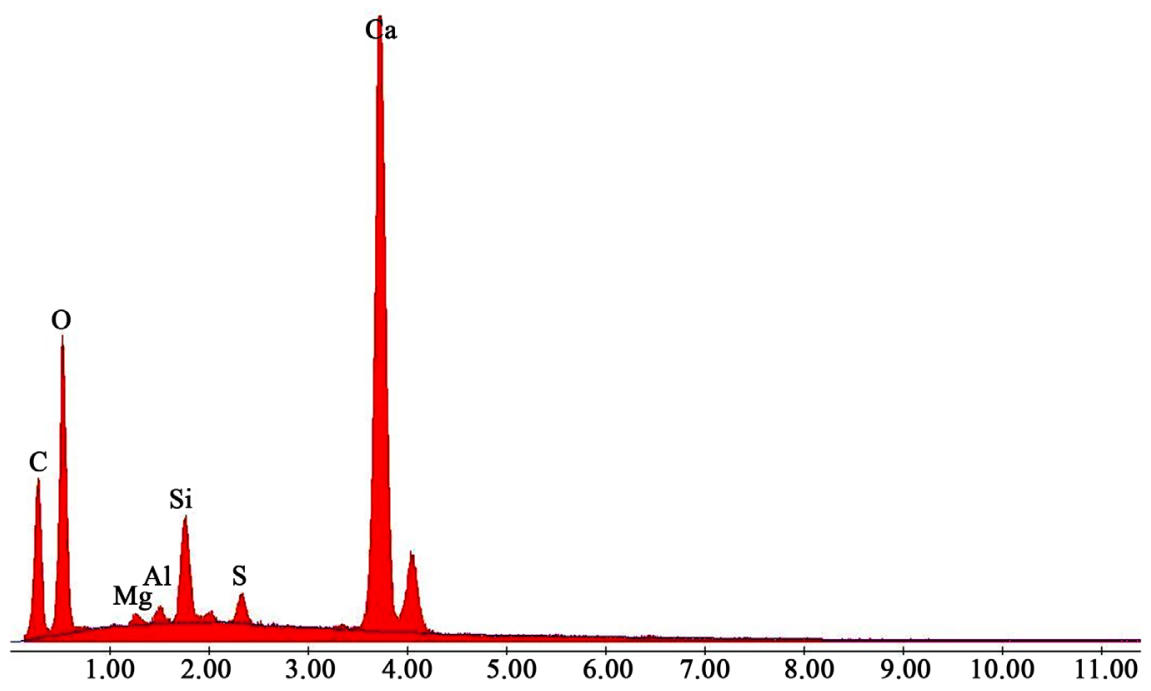

Figure 3. Chemical composition of oil shale in sample 2 from Wadi Al-Shallala area in SEM/EDS analysis.

\subsubsection{Polarized Light Microscopy Analysis of Thin Sections}

The microscopic analysis of oil shale reveals that the primary mineral consists mainly of micritic calcite, while the secondary minerals include carbonate mud and opaque minerals. Calcite, as the major component of the studied samples, occurs as original matrix made up of microcrystalline calcite crystals (micritic and bio-micritic limestone). The sample contains foraminifera filled with microcrystalline calcite crystals. Carbonate mud presented as fine-grained dark brown of micritic calcite. Its presence in clay size cannot be identified by simple polarizing microscopes. In addition, oil shale consist opaque minerals as earthy brown iron oxides and sometimes as small sub rounded dark crystals (Plate 1).

\subsection{Comparison between Oil Shale and Geothermal Potentials for Cooling and Heating Utilization in Sal Village}

\subsubsection{Oil Shale Resource Potential}

Oil shale reserve in the study area was estimated for the current comparative study. It has been found that this oil shale thickness averages $40 \mathrm{~m}$ [25]. Thus, oil shale reserve is calculated to be about 35.8 Million Ton considering that oil shale density is $1.79 \mathrm{~g} / \mathrm{cm}^{3}$, using suggested formula by [29] in multiplying the three parameters together. Daily consumption for air condition cooling for each house in the study area is $5.25 \mathrm{KWh}$ [30]. In the study area, the needs for cooling is 3 months a year, thus the annual energy consumption for cooling is $472.5 \mathrm{KWh}$. The annual energy consumption for cooling for the 2270 houses in Sal is 1.073 GWh. On the other hand, the daily consumption for air condition heating for each house in the study area is $5.45 \mathrm{KWh}$ [30]. In the study area, the needs for cooling is 3 months a year, thus the annual energy consumption for cooling is 490.5 KWh. The annual energy consumption for cooling for the 2270 houses in Sal is $1.113 \mathrm{GWh}$. Consequently, the annual energy consumption for cooling and heating Sal houses is $2.186 \mathrm{GWh}$ which can be covered by direct burning of oil 

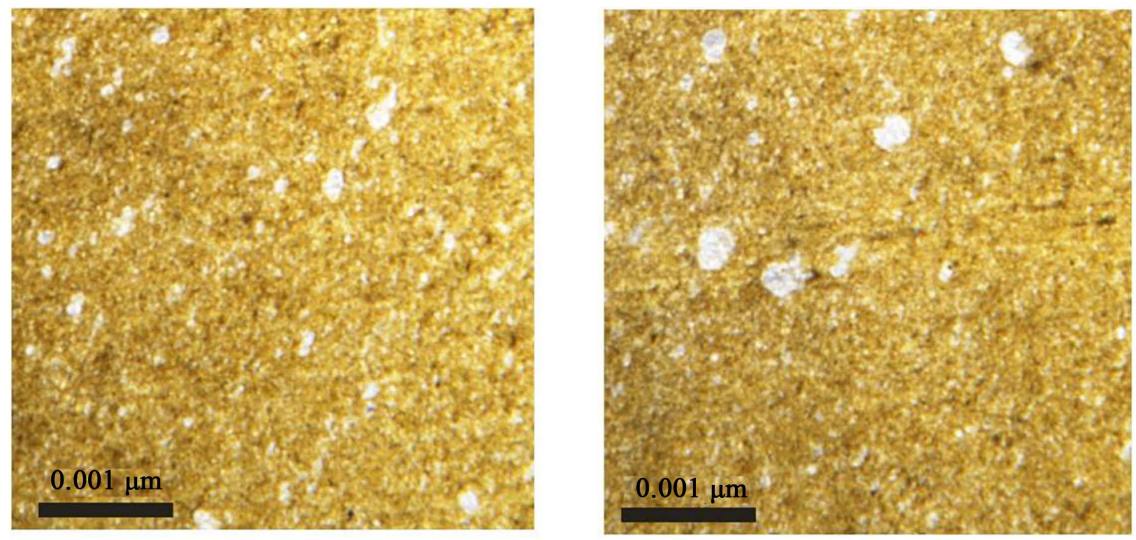

Plate 1. Oil shale under microscope in Plane Polarized Light position (sample 1).

shale. [30] stated that burning one ton of oil shale with 3.33\% organic matter will produce 297.2 KWh of electricity. The extracted energy from burning the whole estimated reserve of 35.8 Million Ton is calculated to be 10,639.8 GWh. For this cooling and heating air conditions, oil shale reserve could supply the village with electricity for more than 200 years.

In addition, another cooling and heating system is suggested; heat pumps (Figure 4). They are essential in modern heating and cooling of residential spaces. Cooling and heating capacities is satisfied by electricity (from burning oil shale) and geothermal system closed loop coupling.

In order to model the possible intake flow rates of different houses cooling and heating capacities, three scenarios were assumed for system simulation i.e.; 50,100 and $200 \mathrm{~m}^{3} / \mathrm{d}$. In these scenarios the annual cooling and heating capacity for Sal houses were calculated. The capacities were converted to GWh assuming 6 daily operational hours in each season. It has been found that oil shale reserve will supply Sal village with cooling and heating in 35, 18 and 9 years for intake flow rate of 50, 100 and $200 \mathrm{~m}^{3} / \mathrm{d}$, respectively. The direct use of oil shale reserve will equivalent to burn about 17 Million oil barrels. This will release 2.71 Million $\mathrm{m}^{3}$ of $\mathrm{CO}_{2}$. Therefore, another clean and sustainable energy resource is evaluated. Geothermal heat pumps in closed system are suggested.

\subsubsection{Geothermal Resource Potential Calculation}

As stated earlier in the methodology, subsurface temperature for shallow closed loop system was modeled to be $22^{\circ}$ at about $150 \mathrm{~m}$ depth. This depth with assigned temperature will be the heat storage in the suggested closed loop system for the annual cooling and heating supply. The system will use the differences between subsurface and air temperature for satisfying cooling and heating needs. Geothermal system will reduce the electricity consumption by decreasing the temperature differences in the electrical operated systems. Heat pumps are essential in modern heating and cooling of residential spaces. Using geothermal energy sources for heating or cooling makes heat pumps a highly sustainable component of air conditioning systems around the world. 


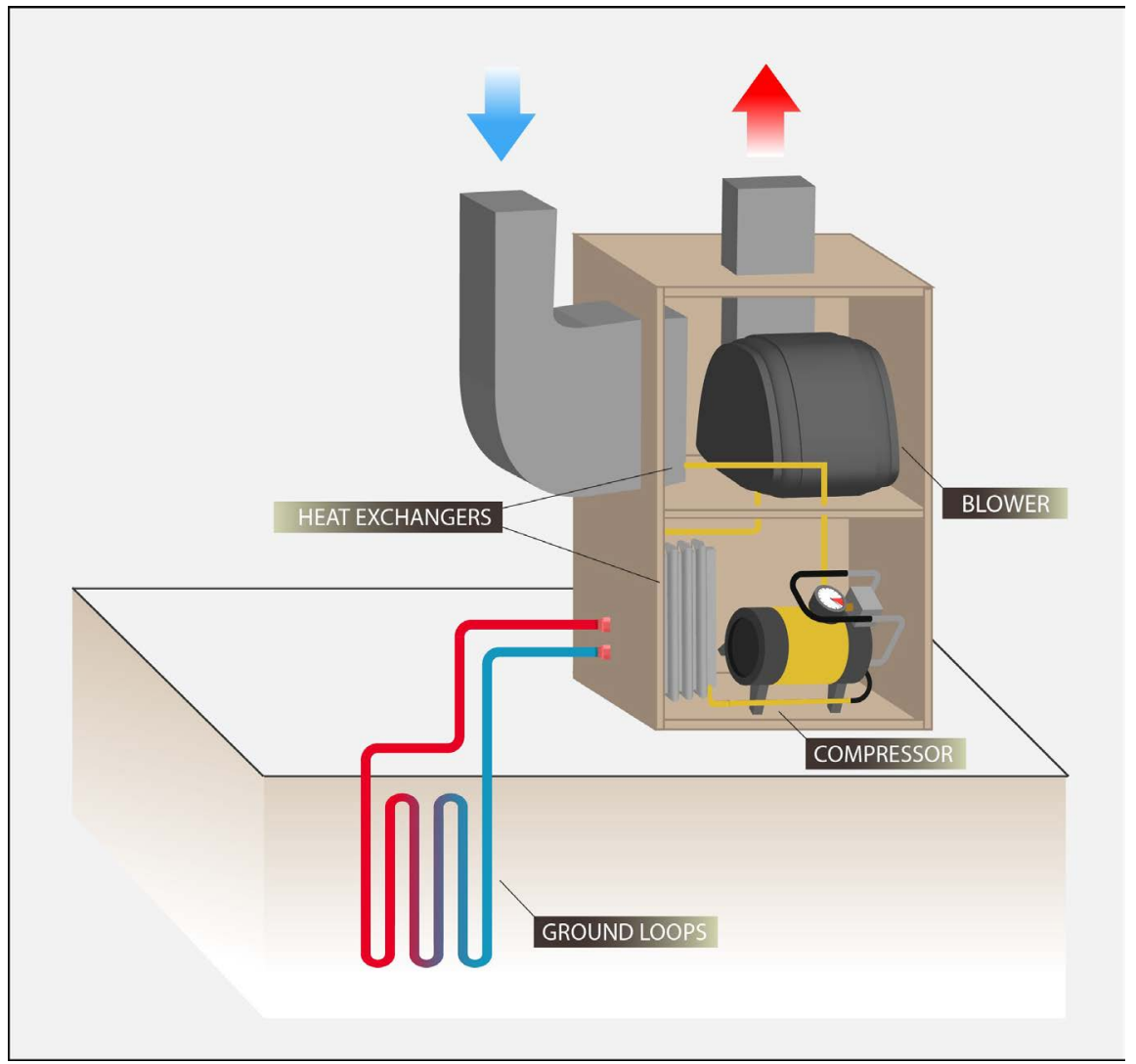

Figure 4. Schematic diagram of closed loop heat pump system.

In summer a reversed process is operated. The subsurface temperature is lower than air temperature. Average room temperature will be $28^{\circ}$, the liquid used in this system will have the same temperature as the surrounding air. This liquid is pumped into pipes. Pipes loop underground will receive this warm fluid. Heat exchange between this fluid and the surrounding subsurface temperature $\left(22^{\circ}\right)$ is developed. Cold liquid is pumped back to the infrastructure and reach the heat pump. The compressors supplied by heat pumps will decrease the temperature from $22^{\circ}$ to $16^{\circ}$. Cool is pushed by fans out to the houses to decrease room temperature.

In winter subsurface temperature is higher than air temperature. Average room temperature will be $10^{\circ}$, the liquid used in this system have the same temperature as the surrounding air. This liquid is pumped into pipes. A horizontal loop of pipes underground will receive this cold fluid. Heat exchange between this fluid and the surrounding subsurface temperature $\left(22^{\circ}\right)$ is developed. Heated liquid is pumped back to the infrastructure and reach the heat pump. The temperature is increased from $22^{\circ}$ to $30^{\circ}$. Heat is pushed by fans out to the houses to increase room temperature. In order to model the possible intake flow rates of different houses cooling and heating capacities, three scenarios were simulated for heat pumps system i.e.; 50, 100 and $200 \mathrm{~m}^{3} / \mathrm{d}$. Annual cooling and heating energy consumptions compared with the annual geothermal heat pumps energy consumptions are listed in Table 3. Comparing the annual cooling/heating 
Table 3. Annual cooling and heating energy electric consumptions scenarios (GWh).

\begin{tabular}{ccccc}
\hline $\begin{array}{c}\text { Intake } \\
\text { flow rate } \\
\left(\mathrm{m}^{3} / \text { day) }\right.\end{array}$ & $\begin{array}{c}\text { Annual cooling energy } \\
\text { consumption } \\
\text { (geothermal heat pump) }\end{array}$ & $\begin{array}{c}\text { Annual heating } \\
\text { energy consumption } \\
\text { (geothermal heat pump) }\end{array}$ & $\begin{array}{c}\text { Annual } \\
\text { cooling energy } \\
\text { consumption }\end{array}$ & $\begin{array}{c}\text { Annual } \\
\text { heating energy } \\
\text { consumption }\end{array}$ \\
\hline 50 & 60.2 & 80.2 & 200.5 & 120.3 \\
100 & 120.3 & 160.4 & 401.0 & 240.6 \\
200 & 240.6 & 320.8 & 802.0 & 481.2 \\
\hline
\end{tabular}

energy consumption with the annual cooling/heating geothermal heat pumps consumption, it has been found that geothermal heat pumps save $60 \%$ of electricity consumption in heating and $50 \%$ in cooling systems (Table 3 ).

The environmental benefits from geothermal system implementation will be a reduction in energy consumption as electricity and fuel oil through the replacement of the conventional systems. The savings in fuel oil will be about 9.35 Million barrels. While the reduction of $\mathrm{CO}_{2}$ emotions will be dropped to 1.5 Million $\mathrm{m}^{3}$. Generally the environmental impacts of geothermal power generation and direct use are minor, controllable and negligible. Despite the reduction of geothermal resources emissions, local environmental impacts should be considered especially on long run operation.

\section{Conclusion}

Oil shale in Wadi Al-Shallala is investigated into its minerals, chemical composition and hydrocarbon potential. It is found that Calcite is the main mineral constituents. Some other Magnesite, Ferrisilicate and Zaherite are presented, too. Trace elements of Zinc, Cobalt and Molybdenum were exhibited in the examined samples. Calcium oxide and Silicon oxide were composed of $53.41 \%$ of the studied oil shale. In parallel with that, Calcium, Oxygen, Carbon and Silicon were indicated by SEM results. In addition, the microscopic analysis of oil shale reveals that the primary mineral consists of micritic calcite, while the secondary minerals include carbonate mud and opaque minerals. It's found that total organic carbon averages $3.33 \%$ while total carbon content averages $20.6 \%$. Low sulfur contents are noticed in the examined oil shale. Oil shale reserve is estimated to be 35.8 Million Ton. For a nearby Sal village of 2270 houses, assuming direct burning of oil shale, two cooling and heating facilities were evaluated for their energy consumption. Oil shale resource will cover the village cooling and heating demands with generated electricity for more than 200 years if the system is air conditions. Another modern system, heat pumps, is simulated for cooling and heating supply, too. With these pumps, it has been found that oil shale reserve will supply the village with cooling and heating in 35, 18 and 9 years dependent on the intake flow rates of 50,100 and $200 \mathrm{~m}^{3} / \mathrm{d}$, respectively. Oil shale reserve burning will release 2.71 Million $\mathrm{m}^{3}$ of $\mathrm{CO}_{2}$. Therefore, another renewable energy resource is suggested. Geothermal heat pump system for shallow closed loop is simulated. Geothermal heat pumps are found to save $60 \%$ of elec- 
tricity consumption in heating and $50 \%$ in cooling systems. This will reduce $\mathrm{CO}_{2}$ emissions to 1.5 Million $\mathrm{m}^{3}$. Consequently, geothermal energy offers considerable advantages rather than conventional oil shale potential.

\section{Acknowledgements}

Authors wish to express appreciation to Prof. Rafie Shinaq, Dr. Habes Mashakbeh and Dr. Islam Al Dabsheh for their discussion and communications. Special thanks for $\mathrm{Al}$ al-Bayt University (AABU) for facilitating the field and lab work for this work as a part of master thesis research. Authors appreciate the help of Eng. Mo'men Bani Issa and Eng. Ahmad Alraies for their numerous help in calculations. Many thanks for Royal Scientific Society (RSS) and Natural Resources Authority (NRA) support. Grateful thanks to Water, Environment and Arid Regions Research Center (WEARRC) staff at AABU for their hand in mineralogical and chemical analysis. Finally, acknowledgment with gratitude goes the reviewers for their useful suggestions.

\section{Conflicts of Interest}

The authors declare no conflicts of interest regarding the publication of this paper.

\section{References}

[1] Al-Harahsheh, M., Al-Ayed, O., Robinson, J., Kingman, S., Al-Harahsheh, A., Tarawneh, K. and Barranco, R. (2011) Effect of Demineralization and Heating Rate on the Pyrolysis Kinetics of Jordanian Oil Shales. Fuel Processing Technology, 92, 1805-1811. https://doi.org/10.1016/j.fuproc.2011.04.037

[2] Alnawafleh, H., Tarawneh, K., Siavalas, G., Christanis, K. and Iordanidis, A. (2016) Geochemistry and Organic Petrography of Jordanian Sultani Oil Shale. Open Journal of Geology, 6, 1209-1220. https://doi.org/10.4236/ojg.2016.610089

[3] Alnawafleh, H.M., Fraige, F.Y., Tarawneh, K.E., Sarairah, I.A. and Al-Khatib, L.A. (2016) Fractional Yield, Extract Composition and Variability from Jordanian Oil Shales. Journal of Analytical Sciences, Methods and Instrumentation, 6, 51-63. https://doi.org/10.4236/jasmi.2016.63007

[4] Alali, J., Abu Salah, A., Yasin, S.M. and Al Omari, W. (2015) Oil Shale. In: Sahawneh, J. and Madanat, M., Eds., Ministry of Energy and Mineral Resources, Mineral Status and Future Opportunity, Amman.

[5] Abu-Hamatteh, Z.S., Al-Shawabkeh, H. and Ali, F. (2008) An Overview of the Jordanian Oil Shale: Its Chemical and Geologic Characteristics, Exploration, Reserves, Research Gate Journal.

[6] Hrayshat, E.S. (2009) Status and Outlook of Geothermal Energy in Jordan. Energy for Sustainable Development, 13, 124-128. https://doi.org/10.1016/j.esd.2009.05.004

[7] Al-Zyoud, S. (2012) Geothermal Cooling in Arid Regions: An Investigation of the Jordanian Harrat Aquifer System. Dissertation, XIII und 140 S., 61 Abb., 16 Tab., 1 CD-ROM, Technische Universität Darmstadt.

[8] Schäffer, R. and Sass (2014) The Thermal Springs of Jordan. Environmental Earth Sciences, 72, 171. https://doi.org/10.1007/s12665-013-2944-4 
[9] Hähnlein, S., Bayer, P., Ferguson, G. and Blum, P. (2013) Sustainability and Policy for the Thermal Use of Shallow Geothermal Energy. Energy Policy, 59, 914-925. https://doi.org/10.1016/j.enpol.2013.04.040

[10] Thnebat, M.A. (2003) Hydrological Study of Wadi Esh-Shallala Yarmouk Basin. MSc Thesis, University of Jordan, Amman.

[11] Shinaq, R. and Bandel, K. (1998) Lithostratigraphy of the Belqa Group (Late Cretaceous) in Northern Jordan. Geol-Paleont, 163-184

[12] Moh'd, B.K. (2000) The Geology of Irbid and Ash Shuna Ash Shamaliyya (Waqqas): Map Sheets No. 3154-II and 3154-III. The Hashemite Kingdom of Jordan, Natural Resources Authority, Geology Directorate, Geological Mapping Division, Amman.

[13] Moh'd, B. (1997) The Geology of Irbid Area. Map Sheet 3155 II, Bull.46. The Hashemite Kingdom of Jordan, Natural Resources Authority, Geology Directorate, Geological Mapping Division, Amman.

[14] Jarvie, D. (1991) Total Organic Carbon (TOC) Analysis. In: Merrill, R., Ed., Source and Migration Processes and Evaluation Techniques, American Association of petroleum Geologist, Tulsa, 113-118.

[15] Loring, D.H. and Rantala, R.T.T. (1992) Manual for the Geochemical Analyses of Marine Sediments and Suspended Particulate Matter. Earth-Science Reviews, 32, 235-283. https://doi.org/10.1016/0012-8252(92)90001-A

[16] Verardo, D.J., Froelich, P.N. and McIntyre, A. (1990) Determination of Organic Carbon and Nitrogen in Marine Sediments Using the Carlo Erba NA-1500 Analyzer. Deep Sea Research Part A: Oceanographic Research Papers, 37, 157-165. https://doi.org/10.1016/0198-0149(90)90034-S

[17] Kugler, W. (2003) X-Ray Diffraction Analysis in the Forensic Science: The Last Resort in Many Criminal Cases. International Centre for Diffraction Data, 46, 1-16.

[18] Hou, X. and Jones, T. (2000) Inductively Coupled Plasma/Optical Emission Spectrometry Encyclopeida of Analytical Chemistry. John Wiley and Sons Ltd., Chichester.

[19] Welton, J.E. (1984) SEM Petrology Atlas. American Association of Petroleum Geologists, Tulsa, Okla.

[20] Swarieh, A. (2005) Heat Sources of the Groundwater in the Zara-Zarqa Ma'in-Jiza Area, Central Jordan. University of Karlsruhe, Karlsruhe, Germany.

[21] Pollack, H., Hurter, S. and Johnson, J. (1993) Heat Flow from the Earth's Interior: Analysis of the Global Data Set. Reviews of Geophysics, 31, 267-280. https://doi.org/10.1029/93RG01249

[22] Al Mahamid, J. (2005) Integration of Water Resources of the Upper Aquifer in Amman-Zarqa Basin Based on Mathematical Modeling and GIS, Jordan. Freiberg Online Geology, Freiberg.

[23] Williams, H., Ramini, H. and Alzyoud, M. (1990) Regional Petroleum Geochemistry of Jordan. Natural Rescources Authority, Amman, 66 p.

[24] Ministry of Water and Irrigation (MWI) (2018) Groundwater Wells Data Base. Unpublished Reports.

[25] Merrill, R. (1991) Source and Migration Processes and Evaluation Techniques. American Association of Petroleum Geologist, Tulsa, USA.

[26] Van der Zwaan, G.J., Jorissen, F.J. and De Stigter, H.C. (1990) The Depth Dependency of Planktonic/Benthic Foraminiferal Ratios: Constraints and Applications. Marine Geology, 95, 1-16. https://doi.org/10.1016/0025-3227(90)90016-D

[27] AlSoud, H. (2019) Microfacies Analyses, Micropaleontology and Paleo Environ- 
ment of Oil Shale Depostts in Wadi Al-Shallala, Jordan. Unpublished Master Thesis, $\mathrm{Al}$ al-Bayt University, Al-Mafraq, Jordan.

[28] Hamarneh, Y. (1998) Oil Shale Resources Development in Jordan. Natural Recourses Authority Report, the Hashemite Kingdom of Jordan.

[29] US Geological Survey Oil Shale Assessment Team (2010) Oil Shale Resources of the Uinta Basin, Utah and Colorado: US Geological Survey Digital Data Series DDS-69-BB, 7 Chapters.

[30] Ministry of Energy and Mineral Resources (MEMR) (2018) Annual Reports and Other Published Reports. 